\title{
Finding Voice: Debating in Secondary School English
}

Fiona Stockdale

\begin{abstract}
This essay explores the place of debating, talk and group work in the Secondary English classroom. It discusses the ways in which pupils in one student teacher's year 7 class thrive in the dialogic classroom against the backdrop of curricular and attitudinal change. It considers the importance of talk and debate amongst the 'communities of practice' in schools and universities in empowering teachers to challenge and navigate policies, theories and practices. In exploring the role of play, student experiences and different forms of talk, this essay highlights their vital importance in relation to teaching and learning in English and in the formation of English teachers.
\end{abstract}

\section{Keywords}

Oracy; talk; debate; role; collaboration; teacher development

\section{The contested place of talk and debating in English classrooms}

We just had a day off timetable doing drama and debate with the year nines. Students directed a scene of their choice from Macbeth and then we had a debate on who is responsible for Duncan's death. It was very engaging. Students came up with all sorts of questions and answers. We picked one from each group to be one of the characters and we divided them in two groups of three each. Macbeth, Lady Macbeth and one of the weird sisters were in one group and Banquo, Macduff and Malcolm were in the other. It was very interesting. Macbeth's lack of remorse was one of the big issues along with the witches' influence. One student called one witch 'a spoon' for stirring things up and asked her to own up!

Salma (February 2019)

I haven't had a chance to use debating yet in my NQT year. I've got some tough classes and I've been reluctant to open up and re-organise for a debate.

David (February 2019)

These first-hand accounts of life as a newly qualified teacher (NQT) are from two former students who attended my debating workshop as part of their PGCE, the pre-service teacher education programme on which I teach. They are an intriguing reflection of the wider context and, dare I say, the debate surrounding the role and value of debating, group work, oracy and student independence in the English classroom. They need to be read 
against recent changes in curriculum and assessment policy in England, changes which have devalued the place of talk in the English classroom (cf. Yandell 2013). In England, teachers have felt 'under pressure to neglect the more exploratory and collective aspects of talk' (Richmond 2015, 13). Couple this with the decreasing use of group work in English classrooms and an increasing uncertainty of its value (Bleiman 2016), beginning teachers have reduced confidence and exposure to the ways in which more experienced colleagues successfully use these elements of practice.

The declining use of debating in the classroom is something to be challenged and resisted. In my experience, debating provides a space for students to confidently and critically explore, consider and challenge ideas and concepts with their peers. This occurs not only during the debate itself but also in the exploratory discussions beforehand, both in small student groups and as a whole class with teacher questioning. It provides the opportunity for learners to play, sometimes explicitly so in the embodiment of the character and, at other times, through adopting the distinctive linguistic repertoire that the role dictates. Students have the opportunity to cross-examine their peers, being handed the mantle of the questioner to interrogate different arguments and perspectives on their world. It provides learners with a platform to share their opinions, readings and experiences in a supportive and receptive environment. Debating enables pupils to be 'reflective and critical', providing opportunities for school students to 'take deliberate responsibility for learning and its relationship to the world of understandings, beliefs and values that he or she inhabits' as well as 'taking responsibility for finding connections and examples, asking questions, reinterpreting experience, and searching for new techniques and new ways of understanding relevant to the matter in hand' (Barnes 2008, 14-15).

To investigate the impact of debating on student learning and the practice of beginning teachers, I want to focus on a single observed lesson, taught by Allysia, one of the students on the English PGCE programme. In February each year, the English PGCE team provide a selection of workshops for our students. Allysia opted to attend my debating workshop and showed great enthusiasm for how she might implement the ideas explored in her own classroom. We kept in touch as she began teaching in her second and final practicum, the site of the observed lesson, a boys' comprehensive school in South London. After we had discussed her work with a group of year 7 students, I was interested to observe how Allysia had integrated debating into her practice and schemes of learning as it became apparent that she was operating in a context which placed limited emphasis on the role of talk. Indeed, this was something that Allysia continued to 
reflect upon after the observation. She felt that debating, and talk more generally, was an area of the English curriculum that had limited ascribed value or status for the students in her classes.

Allysia: I think that talk is important in the classroom, but the students here aren't necessarily used to it. They are not used to it being productive and effective so that's why I am trying to do it in my lessons... [Twelve weeks ago] they didn't understand how to structure their talk to be effective. They didn't know how it felt to be allowed to speak. So, I think they were used to answering quite closed questions in a classroom hands up situation, but they were not used to discussing ideas with one another and coming up with an interpretation themselves.

An environment where students feel their voices and opinions are not only 'allowed' but valued creates a classroom where open, developed discourse can take place. The precedence that closed questions seemed to have in this classroom demonstrates a lack of opportunity to 'harness[es] the power of talk to engage children, stimulate and extend their thinking, and advance their learning and understanding' in a 'collective', 'reciprocal', 'supportive', 'cumulative' and 'purposeful' dialogic teaching environment (Alexander 2017, 37-38). Allysia's determination to create this in her classroom relates to her own experiences of schooling as well as to the literature studied and teaching experienced on the PGCE English programme. The consistency of working with the same group of peers and tutor in a seminar group for an academic year, with approaches informed by the principles of dialogic teaching (Alexander 2017) and social constructivism, provides student teachers with direct experience of the power of these approaches in developing learning in classrooms. The 'communities of practice' (Lave and Wenger 1991) established provide student teachers with the opportunity to debate and navigate current policy and pedagogies in light of their reading and classroom experiences. This, however, is only one of the communities to which student teachers belong, with students entering into those of the school and department in each placement. As members of multiple communities, within and between which there are multiple perspectives, the student teacher has the opportunity to engage with a range of views and experiences. As developing practitioners, these dialogic spaces are imperative to their development in their PGCE year and beyond, in their careers as teachers. It was Allysia's history, perspectives and navigation of these multiple communities of practice that made me want to observe her teach in the final part of her PGCE placement. I wanted to see how she had forged her own identity and the possibilities this might hold for her transition to NQT. 


\section{Exploring character (and the world) through a balloon debate}

Allysia had been working for the last 12 weeks with the year 7 class 1 I was to observe, teaching Hamlet in the first half term and Jack London's novel, The Call of the Wild, in the second. Allysia had introduced the students to debating whilst teaching Hamlet, with students completing a formal debate exploring Ophelia's death. On the day of my visit, students were to participate in a 'balloon debate' to explore the characters in The Call of the Wild. Students would work in groups to explore the motivations of a particular character, with one student from each of the groups representing their character in the debate. The other students would become journalists during the debate, making notes and posing questions to the characters. This framing of the debate, with students embodying characters both from the novel and 'real life', provided the opportunity to explore character and the role of a journalist in an integrated manner. In many senses, this framework for the debate acted as 'rule-based play', transforming the students into characters in an 'imaginary situation [which] liberates [them] from situational constraints' (Vygotsky [1966] 2016, 9, 11) within the space of the classroom.

The lesson began with students discussing the media, the role of journalists in gathering evidence and reporting on stories as well as the place of debating in society. Students were buzzing with ideas. There were conversations exploring Donald Trump and 'fake news', Brexit and parliamentary debate as well as the ways students debate with one another in the playground. The boys were excited to share their ideas and examples with the rest of the group. Much like the students observed by Yandell (2014) in Monica's class, the students listened intently to one another and were keen to share their observations and experiences in the welcoming and receptive space that Allysia had created in her classroom. Ethan shared his deft understanding of the power of language in the media by drawing on the example of the way a newspaper had reported on two Manchester City footballers, who had both bought homes for their mothers.

\section{Allysia: Ethan, what do you think?}

Ethan: I think that, erm, it comes down to the journalist coz they - there has been quite a few incidents where the journalists have portrayed certain people wrong and other people in a way so erm, can I give you an example? Allysia: Yeah, that is exactly what I want Ethan: Oh, so erm, there were some journalists and when erm Sterling, Raheem Sterling, he bought a house [Allysia: $\mathrm{mm}$-hmm] and the journalists said he was 'splashing his cash on this big mansion' but when erm Phil 
Foden bought a house, they said erm 'kind footballer buys a house for his Mum' and they were both the same price and they were just portraying someone in a certain way

What Ethan shows here is his mature understanding of the power of language to shape perspectives and the reporting bias that is evident in these news stories. Although Raheem Sterling was not one of the footballers reported as buying the house, this being Tosin Adarabioyo, Sterling did write about the disparity of reporting and the relationship to racism in an Instagram post which was then widely reported by the media (Brown 2018). For the multicultural community of boys in this classroom, this dialogue created the opportunity to highlight the importance of their knowledge and experiences in making meanings as well as their understanding of the media's role in shaping the ways individuals and actions are perceived. This discussion also provided an insight into the access that students have to a range of news sources and the importance of social media in providing the metaphorical and literal links between websites, voices and sources. The open questions posed by Allysia enabled students to make connections between the world outside of the classroom and their lesson, allowing students to 'contribute to the shaping of the verbal agenda and introduce alternative frames of reference' (Hardman 2008, 134). Indeed, it is 'the learner [that] actively constructs the new way of understanding' bringing 'new information, procedures or ways of understanding to bear upon existing ideas, expectations and ways of thinking and acting' (Barnes 2008, $3)$. This was integral to the ways in which the boys contemplated language and role during the debate and in their group preparation.

Allysia asked students to work in small groups to prepare for the debate, with each representing a different character from the novel. She circulated to support the pupils as they worked: asking them questions; probing initial comments; and highlighting interesting ideas that were emerging in the discussions to the whole class. The students explored one another's ideas and critically considered the choices they would make in forming their arguments, thinking about examples and inferences from the novel as well as the language chosen to express themselves. Stephen, who was to play John Thornton in the debate, had just practised his speech with his group. They had been the first group to leave their seats and begin to perform and explore their argument in the 'theatrical space[s]' of the classroom; this group's movement 'enable[d] students to draw on other resources, other possible ways of being the character, other roles and possibilities' (Yandell 2014, 69). In practising one character's speech as a collective, the learners were both the character and the directors. They were able to reflect upon how their character would be presented as well as how 
they might establish their argument for their role in the novel. The 'complex seeing' (Brecht 1978, 44) that students experienced here provided them with a multi-layered exploration of language, character and concepts, both in role and in the construction of the later debate. The framing of the debate as one attended by journalists and the earlier class discussion about the power of language to shape and make meanings acted as important drivers in the way the students went on to consider their own speeches as they worked in small groups. After Stephen had finished his speech in role, a discussion took place around the word 'luckily' in relation to their character's actions in saving the main protagonist, Buck.

Ibrahim: You know when you say . . you should like say luckily like, luckily, coz it was very lucky

Tiago: Yeah to make him positive

Ibrahim: And to make it show like the importance that it was by luck he was saved, by coincidence, by luck.

Stephen: Wait. If you was to say luck. If you say it, it sounds like you just did it for the sake of it, like you didn't really care about it, you just interfered. Ibrahim: No, if you don't care, why would you interfere?

Stephen: You know like you don't care what you do

Isaac: Yeah, like you were lucky to do it, not like you were planning on doing it

Ibrahim: Yeah exactly he wasn't planning on doing it

Isaac: You need to say like you were planning on doing it

Stephen: Yeah, I was planning on doing it

Tiago: Yeah

Ibrahim: Yeah, you can say luckily, that's ok

Tiago: You could say luckily to make him sound more positive

Stephen: Say it like I'm planning on it. I at least did it. Luckily, I came to save Buck. This makes me the best because I was a lifesaver to Buck who is the main character of the story

Ibrahim: Plus, there is no problem using hyperbole

What is evident in this interaction is the ways in which the boys are making and negotiating meanings with one another. They think critically about how they will persuade the audience of journalists as well as being true to their readings of the novel. The exploration of the word 'luck' and how this could be viewed and best used in an utterance demonstrates the students' understanding that 'language is not a neutral medium that passes freely and easily into the private property of the speaker's intentions; it is populated - overpopulated - with the intentions of others' (Bakhtin [1975] 1981, 293-294). It is clear from the dialogue that the students are 
scrutinising the many ways the other debaters and journalists may perceive their 'actions' as John Thornton and their desire to emphasise his kind and thoughtful traits. Allysia facilitated this by providing the learners with the space to explore and 'play' in their roles, encouraging collaboration and role switching to critically consider the representation of their argument through language. Indeed, Stephen's comments as John Thornton towards the end of the discussion demonstrate the power of this role-switching in the ways in which he continues to negotiate meanings, rehearse and discuss with his peers. The complex work that the learners are doing here emphasises the importance of debate in the classroom and, more generally, the importance of creating opportunities for different forms of and purposes for talk (Alexander 2017, 38) in a supportive dialogic space.

\section{Disrupting expectations: different perspectives on classroom talk}

It was during this part of the lesson, when all students were collaborating in groups, that a senior member of staff stood at the doorway of the classroom. He remained there for around 10 minutes, looking in at the learners, Allysia, myself and the class teacher, and seemed to consider whether he should intervene in the lesson. His presence, and the implication that this presence had, affected Allysia. She brought the students back together and asked them to use 'quieter voices' and 'focus'. In the discussion afterwards, she said she felt it was perceived by some members of staff that a classroom where there was student-led talk and 'noise' was seen as one where the teacher had 'lost control' rather than the purposeful and exploratory space I had experienced. The discussions between the groups of boys were impassioned, thoughtful and complex. The space that Allysia had provided for this to happen meant that students were given the opportunity to have rich meaning-making experiences with their peers which, when happening for an entire class at once, can sometimes be loud!

This moment and the later dialogue with Allysia made me reflect further on David's email and his position as a beginning teacher in a new school. The perception by others that a 'loud classroom', or one where the students are learning meaningfully via the social and dialogic, is a space where learning is not happening is a deeply concerning development. This troubling landscape, where a fear of reproof strangles creative planning decisions at their inception, has profound implications for students' learning in the classroom. As a beginning teacher, navigating the complexities of school life, schemes of learning and assessment culture (prominent for both students and staff), it can be difficult to then negotiate how to develop this area of practice when it is not something which is encouraged nor regularly enacted by experienced colleagues. 
However, the landscape is not entirely bleak. When mentoring relationships create spaces for 'collaborative exchange' which 'help to develop shared understandings about the meanings of practice' (Heilbronn 2010, 37), practitioners are able to enter into a meaningful dialogue guided by their experiences and theoretical ideas. When observations are approached formatively, they provide opportunities for discussions of moments and choices in lessons, with this thinking and dialogue benefitting both the observer and the observed. Practitioners engaging in 'wellgrounded reflection', 'to reach new and productive understandings . . . "new" possibilit[ies] of action or conceptualisation[s]' (Heilbronn 2010, 38) are guided by the experiences, discussions and debates that take place within their communities of practice. Talk allows teachers to continue to learn, develop and maintain a critical perspective. These same principles concerning the very nature of learning must extend to their classrooms and learners. It is vital, then, that teacher educators continue to encourage their student teachers to explore talk-based strategies in their classrooms. Student teachers must find the spaces in schemes of learning to use talk-based strategies to give voice to the students they teach and to the colleagues with whom they work with and learn from in school. It is only through these exploratory communities of practice that colleagues can continue to develop, analyse and interrogate practices and policies in their own school communities.

As might be inferred by Allysia's comments at the beginning of this piece, not all students were able to enter the 'play' of the debate as easily as others. Michael represented his group in role as Buck. What was most interesting about his initial speech in the debate was that he and his group had formulated their response around the structure and commonly used sentence starters of PEE (point, example, explain, cf. Gibbons 2019), often used as a frame for analytical essay writing. Despite beginning his speech in role as Buck, Michael very quickly alters to speak as himself, representing his group's perspective on the novel and character.

Michael: Hello I'm Buck. And Buck is a dog that cares about others. This is shown by the quote 'unselfish love'. This quote is used when John Thornton is in the river and Buck saves him drastically. This shows unselfish love because he risks his life for John Thornton. Buck thinks about other people before himself. Talking back to my previous quote point, he saved John. Instead of thinking what he was gonna do and go away, he was willing to risk his life. Think of it this way, Buck's life has been a rollercoaster. Things were very good but, after he left Judge Miller's house, people started 
treating Buck like he was nothing. This was shown by the quote that erm Hal, Charles and Mercedes said they treated Buck like he was nothing. This shows (timer noise) ahhh!

Michael and his group were trying to navigate the complexities of 'playing' in the imagined situation of the debate whilst also being acutely aware that they are concurrently existing in the real situation of an English classroom, a space where they believe different rules remain. Rules which tend to prioritise formal analytical writing over more creative responses and 'in role' experiences. Rules which mean that 'PEE-ing [is seen] as proper writing' (Gibbons 2019, 43) and, as such, proper speech. Michael's group did not move to the 'theatrical spaces' (Yandell 2014, 69) in their preparation for the debate but rather remained seated throughout, practising at the table and crafting their response in their books.

\section{Taking ownership: the power of collaborative work in role}

In the next stage of the debate, however, Allysia reiterated the need for the speakers to communicate in role. As part of the defence of their own character's importance in the novel, students were asked to comment on other characters taking part in the debate.

Michael: Hello I am Buck. And, unlike these other characters, I have been through a lifelong journey [about] unlike many wolves . ... First of all, I was with Judge Miller who was very nice but then I moved on to other people who hated me and destroyed me like Francois who treated me brutal[ly]. Francois, (pointing to the student in character as Francois) because you treated me badly and, also well yeah, and also (patting chest as he speaks) I've been abused, I been hit with the club. I don't know why; I didn't do anything! And also, if you (pointing to the student in character as John Thornton) want to say anything about me, I struggled, I saved your life. You could be dead by now; I saved your life. I took you out of the river.

In this interaction, Michael became Buck. He assumed 'the body language, facial expression, and tone of voice of [his] role . . this kind of physical tuning-up is obviously important, a way of getting into the right linguistic gear' (Barrs 1987, 213). His emotive first-person embodiment of character and exploration of relationships with others demonstrate the importance of entering fully into role and the imagined situation of the debate. His linguistic choices in role as Buck illustrate his understanding of the ways in which the audience of journalists could be persuaded to support him as well as his detailed understanding of the novel. The repeated use of the first-person pronoun ' $I$ ' to begin his sentences along with the careful 
order in which he focuses on different characters shows his understanding of how to create a compelling argument. This emerged from Michael stepping wholeheartedly into the world of the debate, understanding and appreciating the validity of his reading and performance without the hindrance of any speech frame or sentence starter.

Throughout the debate, Allysia flexibly moved between the role of 'impartial facilitator' and 'observer', 'organising and facilitating pupils' contributions' (Harwood 1998, 155) as well as allowing the students themselves to lead the discussion and organise the journalistic questioning. This approach empowered learners in their roles, committing the students to the imagined situation of play that framed this lesson. Oscar organised the questioning from the group of journalists who were all keen to probe comments made by the characters, drawing upon their knowledge of the novel. The following interaction involved two journalists, Tegan and Rahim, who questioned Eli who was in role as Hal.

Tegan: My question is for Hal. So why did you punish the animals for no reason by making them go longer miles, longer distances and keeping them there?

Eli (as Hal): I wasn't punishing the animals. I was making them work hard for what they get because what's the point in me treating them and spoiling them, making them do nothing? I must push them and mak[ing] them work hard so that we can achieve our overall goal. Then their food and their rest [will be] our goal.

Rahim: Ok, this is a question for Hal. So, kind of like what Tegan said, why didn't you listen to John when he said don't go past there? Why were you ignorant and not listening to him?

Eli (as Hal): Because . . . I ignored John because I wanted to show that I know how to lead my own pack because, even though I am a beginner and may have died in that circumstance, and I'm alive now (laughter from Eli and the group), so I didn't listen to John because this is not John's pack and this is my pack of dogs. John should be grateful that I have led Buck all this way to be with him because if it wasn't for me coming all this way with Buck, John would be dead right now because if there was no Buck, there would be no John.

Tegan, Rahim and Eli draw upon the rich exploratory discussions throughout the lesson to culminate in this confident, in role exchange. The journalists each present a clear opinion of the character in the way in which they question Eli, implying that Hal is cruel and ignorant to other people's attempts to help, demonstrating the exploration of bias that was considered 
earlier in the lesson. The cooperative nature of their questioning, building upon one another's ideas to press Hal to develop his response, demonstrates their focused engagement in the debate and understanding of how journalists might build their arguments (and how they tend to operate as a pack). Eli's responses show his detailed knowledge of the novel but also an astute understanding of how to portray his character as favourably as possible via his language choices. Replacing the word 'punish', as stated in Tegan's question, with the phrase 'work hard' shows Eli's skill in reframing the narrative to generate positive connotations of Hal's actions. Moreover, his skill in deflecting the second question to refocus the journalists on his role in bringing Buck and John Thornton together shows his persuasive skill as well as his understanding of $\mathrm{Hal}$ as a wily character. Eli is also able to engage his audience by joking about the different play-based situations that he and the class are operating in, highlighting Hal's resurrection in this debate, to the utter delight of his peers. His careful bending of the rules of play shows Eli's understanding of how to best exploit his multi-layered role in the debate and engage his audience of journalists and peers.

In allowing students to take ownership of the debate whilst embodying their roles, Allysia transformed the classroom into a new performance and meaning-making space. As Vygotsky ([1966] 2016, 18) observes, 'In play a child is always above his average age, above his daily behaviour; in play it is as though he were a head taller than himself'. The boys demonstrated this elevation in the ways in which they mastered the discourses of the many roles they enacted throughout the lesson. The opportunity for play and talk provided students with the confidence to explore their understanding of the novel as well as the wider world they inhabit, navigating and making connections between complex, interwoven meanings and interpretations.

By placing the students' experiences at the centre of their exploration in the lesson, we empower the students to shape the meanings and direction of the learning. At a time where the curriculum at key stage three is at perilous risk of losing its distinct identity in favour of extended preparation for GCSE examinations (Hubbard 2017), it is vital that students are provided with ample opportunities to explore the breadth of the subject area. They must be able to develop their own personal responses in their own words to what they encounter, experience and create in dialogic classrooms. Indeed, student teachers themselves must continue to learn in dialogic spaces and have continued opportunities for dialogue within the profession about the vital role talk, play and debate has in developing pupil learning in the English classroom. If English teachers are to 'be brave and creative' and 'use [their] subject expertise to design curriculums that will set pupils' minds alight' (Hubbard 2017), opportunities for regular reflective, 
collaborative discussions between colleagues about their practice and about theories which underpin their choices must be prioritised by school leaders. A supportive environment, where teachers are empowered and given adequate time to explore their own and their colleagues' practice, enables departments to thrive and evolve. Talk and debate must be the essential heart of English if school students and teachers are to critically explore the subject as a community and understand the importance of their voices and identities in the world on either side of the school gates.

\section{Note}

1. Names of pupils have been changed to culturally appropriate pseudonyms.

\section{References}

Alexander, R. 2017. Towards Dialogic Teaching: Rethinking classroom talk. Thirsk: Dialogos.

Bakhtin, M. M. [1975] 1981. The Dialogic Imagination: Four Essays. Edited by Michael Holquist. Translated by Caryl Emerson and Michael Holquist. Austin: University of Texas Press.

Barnes, D. 2008. "Exploratory Talk for Learning." Chap. 1 in Exploring Talk in School: Inspired by the Work of Douglas Barnes, edited by N. Mercer and S. Hodgekinson. London: Sage.

Barrs, M. 1987. "Voice and Role in Reading and Writing." Language Arts 64 (2): 207-218.

Bleiman, B. 2016. "It's Good to Talk - Changing Practice in English: The Start of something big (blogpost)". https://www.englishandmedia.co.uk/blog/making-groups-work-changingpractice -in-english-the-start-of-something-big

Brecht, B. 1978. "The Literarization of the Theatre." In Brecht on Theatre: The Development of an Aesthetic, translated and edited by J. Willett, 4347. London: Methuen.

Brown, L. 2018. "Raheem Sterling Says Newspapers Are Helping to 'Fuel Racism' in Football after Alleged Chelsea Fan Abuse." Independent, December 10. https://www.independent.co.uk/sport/ football/premierleague/raheem-sterling-chelsea-racist-racial-abuse-instagram-chelsea-vsmanchester-city-stamford-bridge-fan-a8674636.html 
Gibbons, S. 2019. “"Death by PEEL?' The Teaching of Writing in the Secondary English Classroom in England." English in Education 53 (1): 3645. doi: $10.1080 / 04250494.2019 .1568832$.

Hardman, F. 2008. “Teachers' Use of Feedback in Whole-class and Groupbased Talk." Chap. 8 in Exploring Talk in School: Inspired by the Work of Douglas Barnes, edited by N. Mercer and S. Hodgekinson. London: Sage. Harwood, D. 1998. "The Teacher's Role in Democratic Pedagogies." Chap. 10 in Children as Citizens: Education for Participation, edited by C. Holden and N. Clough. London: Jessica Kingsley Publications.

Heilbronn, R. 2010. "The Reflective Practitioner." Chap. 3 in Critical Practice in Teacher Education: A Study of Professional Learning, edited by R. Heilbronn and J. Yandell. London: Institute of Education, University of London.

Hubbard, S. 2017. "Sarah Hubbard, Her Majesty's Inspector, and National Lead for English, Reflects on the English Curriculum." Ofsted, November 7. https://educationinspection.blog. gov.uk/2017/11/07/sarah-hubbard-her-majestys-inspector-and-nationallead-for-english- reflects-on-the-english-curriculum/

Lave, J., and E. Wenger. 1991. Situated Learning: Legitimate Peripheral Participation. New York: Cambridge University Press.

Richmond, J. 2015. "Curriculum and Assessment in English 3-19: A Better Plan: The National Curriculum for English from 2015." UKLA. Accessed 10 August 2019. https://www.nate.org.uk/ file/2016/04/The-NationalCurriculum-for-English-from-2015.pdf

Vygotsky, L. S. [1966] 2016. "Play and Its Role in the Mental Development of the Child' Translated by Nikolai Veresov and Myra Barrs." International Research in Early Childhood Education 7 (2): 3-25. doi:10.4225/03/584fa3ec1610d.

Yandell, J. 2013. "It Ain't What You Say . ...” Changing English 20 (4): 341-350. doi:10.1080/ 1358684X.2013.855560.

Yandell, J. 2014. The Social Construction of Meaning: Reading Literature in Urban English Classrooms. Oxford: Routledge. 